\title{
Erratum to: Sox 2 in the adult rat sensory nervous system
}

Taro Koike · Taketoshi Wakabayashi · Tetsuji Mori •

Yasuharu Takamori $\cdot$ Yukie Hirahara $\cdot$ Hisao Yamada

Published online: 6 March 2014

(C) Springer-Verlag Berlin Heidelberg 2014

\section{Erratum to: Histochem Cell Biol}

DOI 10.1007/s00418-013-1158-x

Unfortunately, one of the author's family name (Taro Koike) was published incorrectly in the online publication of the article. The correct family name should be Koike. The complete author group is given below.

Taro Koike, Taketoshi Wakabayashi, Tetsuji Mori, Yasuharu Takamori, Yukie Hirahara, Hisao Yamada.

The online version of the original article can be found under doi: 10.1007/s00418-013-1158-x.

T. Koike · T. Wakabayashi · T. Mori · Y. Takamori · Y. Hirahara ·

H. Yamada $(\bowtie)$

Department of Anatomy and Cell Science, Kansai Medical University, 2-5-1 Shinmachi, Hirakata-City, Osaka 573-1010, Japan

e-mail: yamada@hirakata.kmu.ac.jp 